\title{
Mixed epithelial and stromal tumour of the kidney
}

\author{
Eric Simpson, ${ }^{1}$ Shalini Koppisetty, ${ }^{2}$ Ricardo C Alessio, ${ }^{3}$ Anil Kumar $^{4}$
}

${ }^{1}$ Department of Urology, St John Providence Health System, Madison Heights, Michigan, USA

${ }^{2}$ Department of Infectious Disease, William Beaumont Hospital, Royal Oak, Michigan, USA

${ }^{3}$ Department of Pathology, Crittenton Hospital Medical Center, Rochester Hills, Michigan, USA

${ }^{4}$ Department of Urology, Urology Surgical Associates, Rochester Hills, Michigan, USA

\section{Correspondence to} Dr Eric Simpson, simpsonsurge@gmail.com

Accepted 8 July 2015 CrossMark

To cite: Simpson $\mathrm{E}$, Koppisetty S, Alessio RC, et al. BMJ Case Rep Published online: [please include Day Month Year] doi:10.1136/bcr-2015209373

\section{SUMMARY}

Mixed epithelial and stromal tumour (MESTK) of the kidney is a rare and benign tumour composed of epithelial and spindle cell stromal components with solid and cystic architecture. MESTK is most commonly seen in perimenopausal women, especially those on long-term oestrogen therapy. MESTK is often asymptomatic, detected incidentally on imaging studies. Diagnosis is established by histological examination. Microscopy is reminiscent of ovarian stroma. Malignant transformation, metastasis and recurrences are extremely rare. Treatment is surgical excision of the tumour with usually no recurrences after surgery and good prognosis. We describe a case of MESTK found incidentally on imaging studies.

\section{BACKGROUND}

Mixed epithelial and stromal tumour (MESTK) is a rare, benign and complex renal neoplasm, with cystic and solid components. It is typically found incidentally on imaging for other concerns, and has the appearance of a malignancy. It was first described in 1993 by Pawade and colleagues as cystic hamartoma of the renal pelvis. The term MESTK was proposed by Michal and Syrucek ${ }^{1}$ in 1998.

\section{CASE PRESENTATION}

Our patient was a 64-year-old post-menopausal woman who presented with abdominal pain and gastrointestinal bleeding. She had a medical history including renal scarring on the right kidney evaluated many years ago, hypertension and significant tobacco use. Initial contrast-enhanced CT scan of the abdomen and pelvis showed a left multiloculated upper pole cystic mass measuring $9.7 \times 9 \times 7.8 \mathrm{~cm}$ with areas of enhancement and nodularity (figure 1), raising concern for renal cell carcinoma (RCC). There was no evidence of involvement of lymph nodes or distant metastasis. Nuclear renal scan showed good renal function of the left kidney at 58\% and right kidney at $48 \%$. Urine cytology was negative for malignancy. Surgical exploration was planned for concern of RCC.

\section{INVESTIGATIONS}

\section{Pathology examination of surgical specimen}

On gross examination, the left renal mass was ovoid, $12.2 \times 8.9 \times 7.9 \mathrm{~cm}, 447 \mathrm{~g}$ and partially encapsulated. The majority of the mass was covered by a smooth glistening capsule. Cut section revealed a multiloculated cystic and solid mass, with yellow solid areas and small foci of haemorrhages. Intraoperative frozen section of the mass was atypical spindle cell neoplasm, sarcomatoid renal cell carcinoma or primary renal sarcoma.

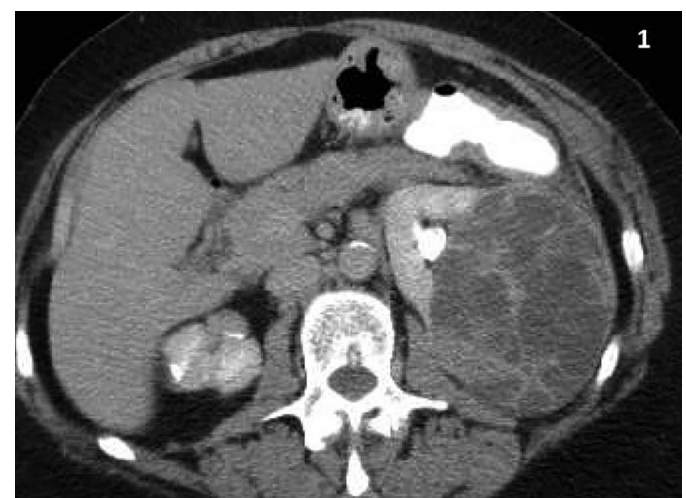

Figure 1 CT scan showing well demarcated large multiloculated partially enhancing nodular left renal mass, with no invasion into aorta/inferior cava and no retroperitoneal lymph nodes.

Microscopically, the tumour was composed of mixed epithelial and stromal proliferation (figure 2) with mild-moderate hypercellularity of the spindle stroma and minimal cytological atypia. There was no significant mitotic activity and tubules were lined by flattened or hobnail epithelial cells (figure 3). Some areas of the stromal proliferation showed a storiform organisation (figure 4), while others resembled ovarian stroma (figure 5). Stromal components were seen bulging into the calyx (figure 6). No areas of necrosis were found. Final diagnosis was MESTK. The original frozen section diagnosis of a malignant neoplasm was corrected.

\section{DIFFERENTIAL DIAGNOSIS}

Multilocular cystic nephroma, multilocular renal cell carcinoma, atypical spindle cell neoplasm, sarcomatoid renal cell carcinoma and primary renal sarcoma.

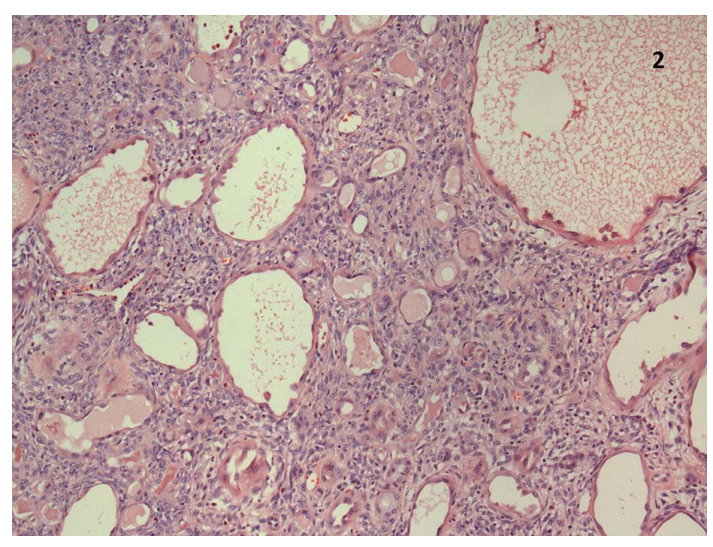

Figure 2 Medium magnification view showing mixed tubules and stroma. 


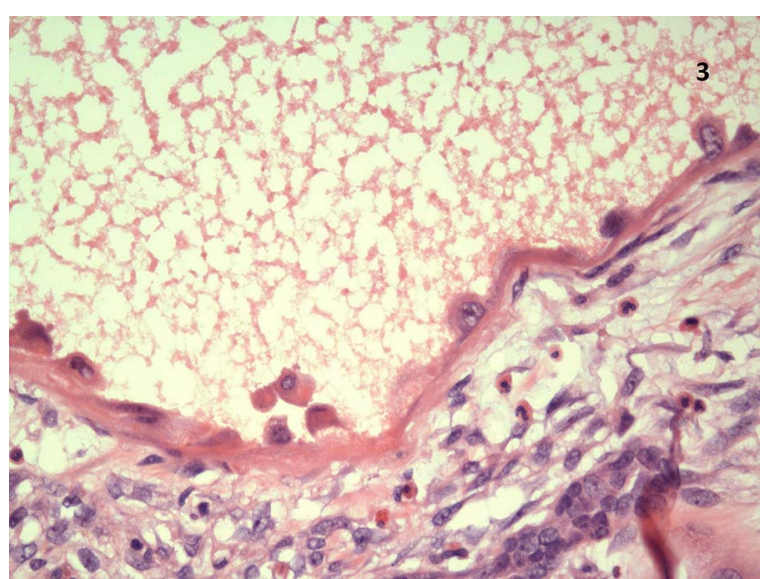

Figure 3 High magnification of hobnail epithelial cells lining the tubules.

\section{TREATMENT}

The patient underwent attempted partial nephrectomy. Intraoperative frozen section of the tumour was atypical spindle cell neoplasm, sarcomatoid renal cell carcinoma or primary renal sarcoma. Subsequently, total nephrectomy was performed due to significant acute surgical changes and focal glomerular sclerosis. The original frozen section diagnosis of a malignant neoplasm was corrected to MESTK from microscopic description.

\section{OUTCOME AND FOLLOW-UP}

The patient was followed up 12 months later with CT scan (without contrast) of the abdomen and pelvis, without any significant changes.

\section{DISCUSSION}

MESTK is a rare benign tumour of the kidney that has been reported recently with unknown aetiology. ${ }^{2}$ It is a new entity and has been included in the WHO 2004 renal tumour classification, as accounting for $1.6 \%$ of all renal neoplasms. All lesions were classified as Bosniak category III or IV. ${ }^{3}$ In the past, it was variously termed as cystic hamartoma of the renal pelvis, adult mesoblastic nephroma and cystic nephroma with cellular or ovarian type stroma. ${ }^{2}$ MESTK is more common in perimenopausal women with a strong correlation in those on long-term hormone replacement or oestrogen therapy, indicating a possible

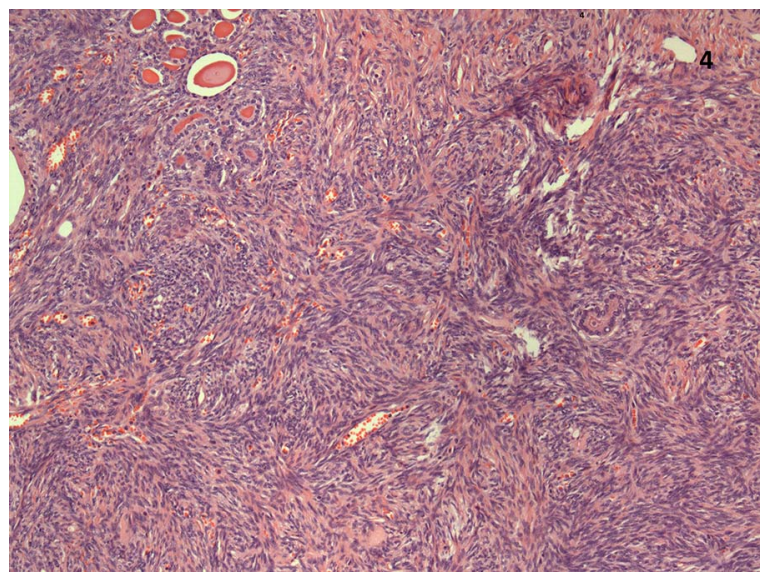

Figure 4 Dense stromal cells in a storiform (pinwheel) pattern.

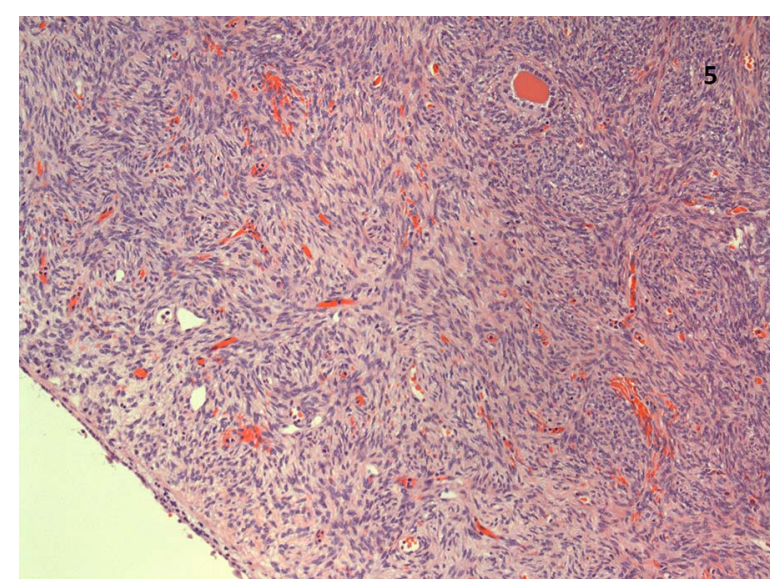

Figure 5 Loose stromal cells resembling ovarian cortex.

hormone-induced mechanism. ${ }^{3} 4$ However, cases have been reported without a history of hormone therapy. About 100 cases of MESTK have been reported in the literature so far, with only 10 cases in men. Men with MESTK also had a history of hormone therapy with leuprolide and diethylstilbestrol. ${ }^{4}$ Female to male ratio is $6: 1$ with mean age being 46 years. ${ }^{4}$ MESTK does not have any distinct clinical and imaging findings, and therefore cannot be diagnosed before surgery. The patients usually present with flank pain, urinary tract infection, haematuria and palpable abdominal mass. Twenty-five percent of cases are asymptomatic and found incidentally on imaging of the abdomen. ${ }^{3}$ The imaging scans cannot differentiate MESTK from other complex renal cysts and cystic nephroma because of their gross morphological similarities. The role of fine-needle aspiration in renal cystic lesions is controversial due to risk of extension of malignant cells, especially if it is a cystic renal cell carcinoma. The definitive diagnosis is made by pathology findings from intraoperative frozen specimen with distinct histopathology features; however, difficulties may arise in making the correct diagnosis, which was indeed what happened in our case. MESTK is a well circumscribed and partially encapsulated dimorphic tumour. The average size of the tumour is about $6 \mathrm{~cm}$ in diameter. ${ }^{2}{ }^{4}$ MESTK is composed of solid and cystic areas, with microscopy showing mixed epithelial and stromal components. The epithelial component consists of clusters of tubules lined by flattened to cuboidal epithelium with eosinophilic cytoplasm and a hobnail appearance. ${ }^{5}$ The stromal

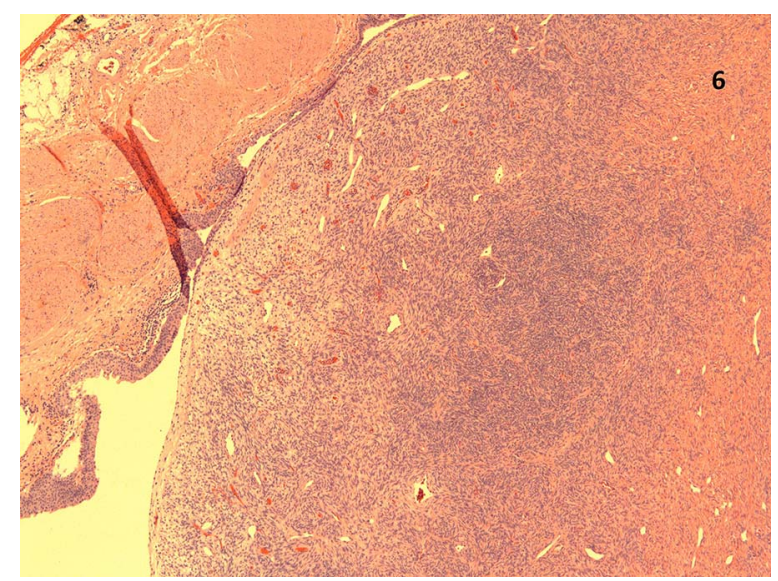

Figure 6 Stromal component bulging into the calyx. 
component consists of spindle cells that resemble ovarian stroma, and display reactivity for oestrogen and progesterone receptors, supporting the hypothesis that hormonal hyperstimulation contributes to tumour genesis of MESTK. ${ }^{4}$ Necrosis, dysplasia, cellular atypia, increased mitotic activity and other malignant features are not associated with MESTK. Prognosis of the tumour is good and complete surgical excision of the tumour is the treatment of choice. Malignant transformation, recurrence and metastasis are rare, however, malignant MESTK

\section{Learning points}

- Mixed epithelial and stromal tumour (MESTK) should be considered a possible diagnosis in cases of cystic renal mass in perimenopausal women with a history of hormonal therapy.

- MESTK is a rare distinctive benign tumour that should be differentiated from other cystic renal neoplasms in order to optimise treatment and preserve kidney function.

- Clinical and imaging findings cannot differentiate MESTK from other cystic renal tumours.

- The definitive diagnosis is made by intraoperative frozen section with distinct histopathology features, but making the correct diagnosis may be challenging, as occurred in our case.

- Although the overall prognosis is favourable, follow-up is necessary to rule out malignant transformation. has been reported, in very few cases, with sarcomatoid components in the stroma. ${ }^{34}$ In 2014, Mudaliar et al ${ }^{6}$ reported a malignant epithelial component arising in a MESTK with malignant transformation of the epithelium classified as renal papillary carcinoma type 1 . The differential diagnosis includes renal tumours with partly cystic morphology, such as multilocular cystic renal cell carcinoma, angiomyolipoma with epithelial cysts, or, in rare cases, synovial sarcoma. ${ }^{2} 4$

Acknowledgements The authors gratefully acknowledge Dr Chirpriya B Dhabuwala for advice on the literature and for reviewing the case report.

Competing interests None declared.

\section{Patient consent Obtained.}

Provenance and peer review Not commissioned; externally peer reviewed.

\section{REFERENCES}

1 Michal M, Syrucek M. Benign mixed epithelial and stromal tumor of the kidney. Pathol Res Pract 1998;194:445-8.

2 Turbiner J, Amin MB, Humphrey PA, et al. Cystic nephroma and mixed epithelial and stromal tumor of kidney: a detailed clinicopathologic analysis of 34 cases and proposal for renal epithelial and stromal tumor (REST) as a unifying term. Am J Surg Pathol 2007:31:489-500.

3 Lane BR, Campbell SC, Remer EM, et al. Adult cystic nephroma and mixed epithelial and stromal tumor of the kidney: clinical, radiographic, and pathologic characteristics. Urology 2008;71:11428.

4 Adsay NV, Eble JN, Srigley JR, et al. Mixed epithelial and stromal tumor of the kidney. Am J Surg Pathol 2000;24:958-70.

5 Montironi R, Mazzucchelli R, Lopez-Beltran A, et al. Cystic nephroma and mixed epithelial and stromal tumour of the kidney: opposite ends of the spectrum of the same entity? Eur Urol 2008;54:1237-46.

6 Mudaliar KM, Mehta V, Gupta GN, et al. Expanding the morphologic spectrum of adult biphasic renal tumors-mixed epithelial and stromal tumor of the kidney with focal papillary renal cell carcinoma: case report and review of the literature. Int J Surg Pathol 2014;22:266-71.

Copyright 2015 BMJ Publishing Group. All rights reserved. For permission to reuse any of this content visit

http://group.bmj.com/group/rights-licensing/permissions.

BMJ Case Report Fellows may re-use this article for personal use and teaching without any further permission.

Become a Fellow of BMJ Case Reports today and you can:

- Submit as many cases as you like

- Enjoy fast sympathetic peer review and rapid publication of accepted articles

- Access all the published articles

- Re-use any of the published material for personal use and teaching without further permission

For information on Institutional Fellowships contact consortiasales@bmjgroup.com

Visit casereports.bmj.com for more articles like this and to become a Fellow 